\title{
COLORECTAL CANCER TREATMENT: AN INTRODUCTION
}

\author{
Antonio Juretić, ${ }^{12}$, Ana Fröbe ${ }^{3}$, Nikola Đaković, ${ }^{1,3}$, Jasmina Marić Brozić3 \\ Fedor Šantek ${ }^{1,2}$, Lidija Beketić-Oreškovićn ${ }^{1,4}$ \\ ${ }^{1}$ Department of Clinical Oncology, School of Medicine, University of Zagreb, \\ Zagreb, Croatia; ${ }^{2}$ Oncology Clinic, University Hospital Centre Zagreb, Zagreb, \\ Croatia; ${ }^{3}$ Department of Oncology and Nuclear Medicine, University Hospital \\ Centre Sestre Milosrdnice, Zagreb, Croatia; ${ }^{4}$ University Hospital for Tumors, \\ University Hospital Centre Sestre Milosrdnice, Zagreb, Croatia;
}

\section{Summary}

Colorectal cancer (CRC) is one of the most frequent type of cancers, and also one of the most frequent causes of death among cancer patients worldwide. Approximately $25 \%$ of newly diagnosed patients with CRC have already developed metastases, and $50 \%$ of all CRC patients will develop metastases over time as the disease progresses. Active oncological treatment of patients having metastatic CRC nowadays includes fluoropyrimidines in combination with irinotecan and/or oxaliplatin \pm monoclonal antibodies (mAbs). Development and introduction of monoclonal antibodies targeting the vascular endothelial growth factor (VEGF; bevacizumab) and the epidermal growth factor receptor (EGFR; cetuximab, panitumumab) in treatment algorithms for patients with wild-type K/N-RAS have significantly improved median overall survival (OS) of patients with metastatic colorectal cancer.

Clinical experience supported by various patohistological and molecular biology data indicates that CRC is a heterogeneous disease. The novel approach to treatment decisions should be patient personalized, i.e. such decisions should be tailored according to patient clinical (age, performance status, comorbidities) and molecular (pharmacogenetic) characteristics, tumor disease stage, tumor location and tumor molecular characteristics and patient preferences. Treatment decision for patients with metastatic CRC must be evidence based. The role of the multidisciplinary team in recommendation preparation is unavoidable.

Keywords: colorectal cancer; biomarkers; chemotherapy; targeted therapy; radiotherapy; personalized medicine. 


\section{INTRODUCTION}

Colorectal cancer (CRC) is one of the most frequent types of cancers and also one of the most frequent causes of death among cancer patients worldwide (1). In 2012 there were 1.4 million new cases worldwide with 649000 deaths. In Europe there were 447000 new cases with 215000 deaths. According to the Cancer Registry data of the Croatian Institute for Public Health, colorectal cancer is the second most common cancer in the Croatian population. In men and women alike it ranks second after, respectively, lung cancer and breast cancer. The mortality rate in Croatia is also very high [1-3].

Clinical experience supported by various patohistological and molecular biology data indicates that CRC is a heterogeneous disease, which can be seen from patients' heterogeneous responses to oncological treatment modalities and their outcomes [4].

The main cause for their malignant transformation is progressive stepwise accumulation of genetic and epigenetic changes in normal colon epithelial cells. Molecular changes associated with cancer cell progression are primarily attributable to genomic instability, which enables the accumulation of somatic aberrations, and can act through three major pathways: microsatellite instability (MSI), chromosomal instability (CIN) and CpG island methylator phenotype (CIMP) [5-6]. These changes may occur either individually or in combination and result in the growth of tumors with different clinical and pathological features.

The novel approach to treatment decisions should be patient personalized, i.e. it should be tailored to patient clinical (age, performance status, comorbidities) and molecular (pharmacogenetic) characteristics, tumor disease stage, tumor location and tumor molecular characteristics and patient preferences. Decisions must be evidence-based. The role of the multidisciplinary team in recommendation preparation is also unavoidable [7].

\section{BIOMARKERS}

\section{RAS testing}

Retrospective analyses of clinical trials for the epidermal growth factor receptor (EGFR) have shown that patients with mCRC whose tumor contains activating mutations in KRAS exon 2 (codons 12/13) do not benefit from EGFR monoclonal antibody therapy. Recent studies like PRIME with panitumumab, CRYSTAL with cetuximab and other studies with EGFR inhibitors have shown that expanded RAS analyses which include KRAS exon 3 and 4 and exon 2, 3 and 4 NRAS analyses 
also predict a lack of response to EGFR monoclonal antibody therapy. These results show that at the time of diagnosing metastatic disease, i.e. before making the decision on the systemic therapy for mCRC patients, the RAS mutation status of the patients' tumor should be assessed. EGFR monoclonal antibody therapy should be conducted only in patients with RAS wild type [8-10].

\section{BRAF testing}

In colorectal cancer BRAF mutations are rather rare. According to data from patients included in clinical trials BRAF mutations were found in between 8 to $12 \%$ of patients with mCRC. This mutation is almost exclusively non-overlapping with RAS mutation. Evidence for BRAF mutation is a negative predictive biomarker for EGFR antibody therapy. A retrospective analysis has shown that two thirds of BRAF mutant patients had a primary tumor located on the right side of the colon. BRAF mutation is a significant negative prognostic marker for patients with mCRC: median survival is 10.4 months compared to 34.7 months for patients with wild-type tumor [11].

\section{MSI testing}

Tumors with MSI (microsatelite instability) retain their chromosomal numbers intact but contain microsatellite repeats, which vary in length due to dMMR (DNA mismatch repair deficiency) and are thought to make contributions to the early steps of tumourigenesis in patients with CRC. Only 4-8\% of all CRC patients represent with MSI. Some data suggest that MSI tumors tend to have a lower disease control rate but most studies show that MSI is not a relevant predictive biomarker for response to chemotherapy [12].

\section{RADIOTHERAPY FOR RECTAL CANCER}

Patients whose colorectal cancer is diagnosed at an early stage (stage I and II) have the best prognosis. Rectal cancer (RC) constitutes approximately one third of all CRC. Rectal cancer management has undergone a dramatic change in the past decade. Until recently surgery remains the primary treatment modality but in spite of "curative" resections, a significant proportion of patients develop local recurrence of the disease ( $20 \%$ to $50 \%$ ). Radical surgical treatment should be based on total mesorectal excision (TME) and for patients having locally advanced rectal cancer TME should be combined with neo-adjuvant or adjuvant radiochemotherapy. Local tumor recurrence is highly correlated with both the depth of penetration of the tumor 
and the number of regional nodes involved by metastatic disease. Recent results of national cooperative group studies and several European randomized trials indicate that a multimodality treatment approach (surgery combined with radiotherapy/ chemotherapy) results in a significantly better outcome than surgery alone [12-14].

\section{METASTATIC DISEASE}

Approximately $25 \%$ of newly diagnosed patients with CRC have already developed metastases, and 50\% of all CRC patients will develop metastases over time as the disease progresses. In the past decade systemic therapy for metastatic colorectal cancer was restricted to fluoropyrimidines. The backbone of chemotherapy in CRC is 5-fluorouracil (5-FU), a pyrimidine analog that disrupts DNA and RNA synthesis. When 5-FU is administered intravenously, it is given with leucovorin, a folate analog that stabilizes thymidylate synthetase and enhances the cytotoxicity of 5-FU. Oral capecitabine is a prodrug that is enzymatically converted to 5-FU in the body and can be used instead of 5-FU. In a metastatic setting its efficacy and patient survival are improved when it is combined with oxaliplatin, a platinum derivative and alkylating agent, or with irinotecan, a topoisomerase I inhibitor that affects DNA repair. In selected patients a feasible treatment option may be a combination of all three agents (FOLFOXIRI). There is evidence for improved response rate and survival with the latter chemotherapy protocol but at the cost of increased toxicity (side-effects), including neurotoxicity and neutropenia. Active oncological treatment of patients having metastatic CRC nowadays includes fluoropyrimidines in combination with irinotecan and/or oxaliplatin \pm monoclonal antibodies (mAbs). Development and introduction of monoclonal antibodies targeting the vascular endothelial growth factor (VEGF; bevacizumab) and the epidermal growth factor receptor (EGFR; cetuximab, panitumumab) in treatment algorithms for patients with wild-type K/N-RAS have significantly improved median overall survival (OS) of patients with metastatic colorectal cancer.

Various studies have investigated whether molecular differences between patients can predict the response to standard chemotherapy drugs and thus facilitate a more personalized approach to chemotherapy. Analyses regarding the genes or their products that may be targeted by such cytostatics or may be involved in the metabolism of these cytostatics or in repairing the damage to the (tumor) DNA molecule caused by these agents are not in routine use. In a disease metastatic setting, including the abovementioned cytotoxic drugs, both the vascular endothelial growth factor (VEGF)-targeted antibody bevacizumab and the epidermal growth factor receptor (EGFR)-targeted antibodies cetuximab and panitumumab have clear 
efficacy when combined with particular cytotoxic chemotherapeutic regimens, the latter group in KRAS and NRAS-wildtype disease only. For bevacizumab we have no predictive parameter or marker. Another drug that targets the VEGF pathway is aflibercept, a recombinant protein with VEGF receptors 1 and 2 that targets VEGFA, VEGF-B, and placental growth factor (PIGF). Regorafenib is also a biologic agent, an oral tyrosine kinase inhibitor that has multiple targets, including VEGF receptors 1,2 , and 3. It was approved for chemotherapy-refractory mCRC in 2013 [15-20].

\section{FUTURE LINES}

We expect our Croatian Health Insurance Agency to soon approve a combination drug trifluridine/tipiracil for third- or fourth-line treatment in metastatic colorectal cancer patients. This drug is an oral combination therapy consisting of trifluridine (a thymidine-based nucleoside analog) plus tipiracil hydrochloride (a novel thymidine phosphorylase inhibitor). It is a dual-targeting formulation whose major mechanism of action is incorporated through trifluridine into DNA during DNA synthesis, thereby causing DNA dysfunction and damage. The thymidine phosphorylase inhibitor (tipiracil) prevents the degradation of trifluridine [21].

Recent publications on checkpoint blocking antibodies (anti-PD-1 / PD-L1) as a novel and effective immunotherapy approach against several types of tumors indicate that this form of immunotherapy can be effective in CRC patients suffering from metastatic disease with microsatellite unstable/mismatch repair-deficient (MSH-H / dMMR) tumors. But this type of treatment should first be approved by regulatory agencies [22].

What has become a hot topic is primary tumor location: right-sided tumors versus left-sided tumors. Right-sided tumor location appears as a negative prognostic factor, and potentially a negative predictive factor for EGFR $\mathrm{mAbs}$, based on a recent large retrospective cohorts' analysis. So, primary tumor location might serve as a surrogate marker of molecular alterations and might have prognostic and possibly predictive implications [23].

Thanks to these multi-agent and multi-modality treatment combinations, the survival period of patients with metastatic CRC has improved for fit patients by up to three to four years on average, but cure is usually not obtained. Fit patients suffering from oligometastatic disease which is amenable to local ablative treatment can expect a better clinical outcome (even a cure) in comparison with patients having overt metastatic disease. 


\section{References}

[1] Globocan 2012. Estimated cancer incidence, mortality and prevalence worldwide in 2012. International Agency for Research on Cancer (IARC). Available from: http://globocan.iarc.fr.

[2] Siegel RL, Miller KD, Jemal A. Cancer statistics, 2017. CA Cancer J Clin. 2017;67:7-30. doi: $10.3322 /$ caac. 21387.

[3] Registar za rak. Hrvatski zavod za javno zdravstvo. Available from: http://www.hzjz.hr/ rak/novo.htm.

[4] Cancer Genome Atlas Network. Comprehensive molecular characterization of human colon and rectal cancer. Nature. 2012;487:330-7. doi:10.1038/nature11252.

[5] Dienstmann R, Salazar R, Tabernero J. The evolution of our molecular understandingof colorectal cancer: what we are doing now, what the future holds, and how tumor profiling is just the beginning. Am Soc Clin Oncol Educ Book. 2014:91-9. doi: 10.14694/ EdBook_AM.2014.34.91.

[6] Stadler ZK, Schrader KA, Vijai J, Robson ME, Offit K. Cancer genomics and inherited risk. J Clin Oncol. 2014;32:687-98. doi: 10.1200/JCO.2013.49.7271.

[7] Binefa G, Rodríguez-Moranta F, Teule A, Medina-Hayas M. Colorectal cancer: from prevention to personalized medicine. World J Gastroenterol. 2014;20:6786-808. doi: 10.3748/ wjg.v20.i22.6786.

[8] Bokemeyer C, Köhne CH, Ciardiello $\mathrm{F}$ et al. FOLFOX4 plus cetuximab treatment and RAS mutations in colorectal cancer. Eur J Cancer. 2015;51:1243-52. doi: 10.1016/j. ejca.2015.04.007.

[9] Douillard JY, Oliner KS, Siena S et al. Panitumumab-FOLFOX4 treatment and RAS mutations in colorectal cancer N Eng J Med. 2013;369:1023-34. doi: 10.1056/NEJMoa1305275.

[10] Heineman V, von Weikersthal LF, Decker T et al. FOLFIRI plus cetuximab versus FOLFIRI plus bevacizumab as first line treatment for patients with metastatic colorectal cancer (FIRE-4): a randomised open label phase 3 trial. Lancet Oncol. 2014;15.1065-75. doi: 10.1016/S1470-2045(14)70330-4.

[11] Tran B, Kopetz S,Tie J et al. Impact of BRAF mutation and microsatellite instability on the pattern of metastatic spread and prognosis in metastatic colorectal cancer. Cancer. 2011;117:4623-32. doi: 10.1002/cncr.26086.

[12] Des Guetz G, Uzzan B, Nicolas P et al. Microsatellite instability: a predictive marker in metastatic colorectal cancer? Target Oncol. 2009;4:57-62. doi: 10.1007/s11523-008-0103-8.

[13] Kapiteijn E, Marijnen CA, Nagtegaal ID et al. Preoperative radiotherapy combined with total mesorectal excision for resectable rectal cancer. N Engl J Med. 2001;345:638-46. doi: 10.1056/NEJMoa010580.

[14] van de Velde CJ, Boelens PG, Borras JM et al. EURECCA colorectal: multidisciplinary management: European consensus conference colon and rectum. Eur J Cancer. 2014;50:1. e1-1.e34. doi: 10.1016/j.ejca.2013.06.048. 
[15] NCCN clinical practice guidelines in oncology: Colon cancer, version 2.2017. Available from: http://www.nccn.org.

[16] NCCN clinical practice guidelines in oncology: Rectal cancer, version 3.2017. Available from: http://www.nccn.org.

[17] ESMO consensus guidelines for the management of patients with metastatic colorectalcancer. Available from: http://www.esmo.org/Guidelines/Gastrointestinal-Cancers/ Management-of-Patients-with-Metastatic-Colorectal-Cancer.

[18] Seeber A, Gastl G. Targeted therapy of colorectal cancer. Oncol Res Treat. 2016;39:796802. Doi: $10.1159 / 000453027$.

[19] Gustavsson B, Carlsson G, Machover D et al. A Review of the evolution of systemic chemotherapy in the management of colorectal cancer. Clin Colorectal Cancer. 2015;14:1-10. doi: 10.1016/j.clcc.2014.11.002.

[20] Mahipal A, Grothey A. Role of biologics in first-line treatment of colorectal cancer. J Oncol Pract. 2016;12:1219-28. doi: 10.1200/JOP.2016.018382.

[21] Grothey A, Marshall JL, Seery TE. Current options for third-line treatment of metastatic colorectal cancer. Clin Adv Hematol Oncol. 2016; 14 (3 Suppl 3):1-15.

[22] Le DT, Uram JN, Wang H et al. PD-1 blockade in tumors with mismatch-repair deficiency. N Engl J Med. 2015;372:2509-20. doi: 10.1056/NEJMoa1500596.

[23] Tejpar S, Stintzing S, Ciardiello F et al. Prognostic and predictive relevance of primary tumor location in patients with ras wild-type metastatic colorectal cancer: retrospective analyses of the CRYSTAL and FIRE-3 trials. JAMA Oncol. 2017;3:194-201. doi:10.1001/ jamaoncol.2016.3797. 
Sažetak

\section{Liječenje kolorektalnog raka: uvodnik}

Rak debelog crijeva (CRC) jedan je od najčešćih vrsta raka, a također i jedan od najčešćih uzroka smrti kod pacijenata oboljelih od raka u svijetu. Oko 25\% novodijagnosticiranih bolesnika s CRC u trenutnku postavaljnja dijagnoze već je razvilo metastaze, a 50\% svih bolesnika s kolorektalnim karcinomom razviti će metastaze s vremenom kako bolest napreduje. Aktivno onkološko liječenje pacijenata s metastatskim CRC bazira se na fluoropirimidinima (5FU) u kombinaciji s irinotekanom i / ili oksaliplatinom \pm monoklonska protutijela (Mab). Razvoj i uvođenje monoklonskih antitijela usmjerenih na faktor rasta vaskularnog endotela (VEGF; bevacizumab) i receptor epidermalnog faktora rasta (EGFR; cetuksimab, panitumumab) u bolesnika s divljim tipom K/ N-RAS, u algoritam za liječenje, znatno je poboljšano prosječno preživljavanja (OS) bolesnika s metastatskim rakom debelog crijeva. Kliničko iskustvo, kao i patohistološki i molekularni podatci o biologiji tumora, pokazuju kako je CRC heterogena bolest. Novi pristup u liječenju mCRC treba biti individulano usmjeren na svakog pojedinog pacijenta, tj trebaju biti prilagođeni parametrima pacijenta (dob, klinički status, komorbiditeti) i parametrima tumora: stadiju bolesti, lokaciji tumora i molekularnim obilježljima tumora, te preferenciji pacijenta. Liječenje bolesnika s metastatskim CRC mora se temeljiti na dokazima i biti u skladu sa smjenicama stručnih društava. Uloga multidisciplinarnog tima u odluci o preporuci i provođenju terapije danas je mandatorna.

Ključne riječi: kolorektalni rak; biomarkeri; kemoterapija; ciljana terapija; radioterapija; personalizirana medicina. 